\title{
THE POPULATION GENETICS OF ARABIDOPSIS THALIANA
}

\section{POPULATION STRUCTURE}

\author{
M. E. JONES \\ Department of Genetics, University of Birmingham, England
}

Received 13.vii.70

\section{INTRODUGTION}

IN a previous paper (Jones, 1971), the results from three experiments were considered in relation to the information they provided on the nature of the breeding system in natural populations of Arabidopsis thaliana. Contrary to expectation, these results strongly suggest that some outbreeding occurs in natural populations of this species.

The present paper is concerned with the results of the first of these three experiments and with the information it provides on the distribution of variation between populations, as well as between families within populations. As in the previous paper, six populations are concerned in all, four of which were obtained from disused railway track sites in Warwickshire, and two from garden habitats. In addition to the time of flowering, two further quantitative characters are included here, namely, height and rosette width. Both characters were measured at the time of flowering and measurements were made in millimetres.

Since only five plants were sampled from each of the six populations, the experiment is rather smaller than is desirable. It was designed, however, for exploratory purposes. Furthermore, as will be seen, the magnitude of the differences is sufficiently large for many of the comparisons of interest to leave little doubt that these are genuine. Nevertheless, in view of the small sample size the results need to be interpreted with some caution.

\section{Materials AND MEthods}

The details of the locations and origins of the populations are given in table 1 of the previous paper. Ten seeds were sown from each of the 30 plants sampled, five in each of two independently randomised blocks. The experiment thus consisted of 300 plants in all. (For further experimental details, see Jones, 1971.)

\section{RESUlts}

\section{(i) Variation between populations}

It is clear from the analyses of variance (table 1) that populations show considerable differences with respect to all three characters measured. Much of this variation, however, falls to a comparison between the two types of habitat. Thus, in comparison with populations from garden habitats those from railway tracks flower later, are taller and have larger rosettes at flowering time (table 2). Indeed, in the case of rosette width, all the variation between populations falls to the comparison between habitat types (table 3 ). 


\section{TABle 1}

Analysis of variance

\begin{tabular}{|c|c|c|c|c|}
\hline Item & d.f. & M.S. (height) & M.S. (R. width) & M.S. (F. time) \\
\hline Populations & 5 & $21,636 \cdot 132 * * *$ & $24,255 \cdot 477 * * *$ & $21,028 \cdot 497 * * *$ \\
\hline between habitats & 1 & $82,347 \cdot 243 *$ & $112,347 \cdot 807 * *$ & $198,417 \cdot 066^{*}$ \\
\hline within habitats & 4 & $6,458 \cdot 355 \quad 5-10 \%$ & $2,194 \cdot 895$ & $9,444 \cdot 789 *$ \\
\hline Bewteen families & 24 & $2,697 \cdot 235^{* * *}$ & $1,195 \cdot 668 * * *$ & $2,350 \cdot 743 * * *$ \\
\hline Within families & 214 & $871 \cdot 531$ & 263.658 & $86 \cdot 865$ \\
\hline
\end{tabular}

TABle 2

Family and population means

\begin{tabular}{|c|c|c|c|c|c|c|c|c|}
\hline \multirow{2}{*}{$\begin{array}{l}\text { Pop. } \\
1\end{array}$} & Fam. & $\mathrm{N}$ & \multicolumn{2}{|c|}{ Height } & \multicolumn{2}{|c|}{ Rosette width } & \multicolumn{2}{|c|}{ Flowering time } \\
\hline & $\begin{array}{l}1 \\
2 \\
3 \\
4 \\
5\end{array}$ & $\begin{array}{c}10 \\
8 \\
10 \\
4(5) \\
2(8)\end{array}$ & $\left.\begin{array}{r}73 \cdot 40 \\
98 \cdot 00 \\
150 \cdot 60 \\
72.75 \\
79.00\end{array}\right\}$ & $102 \cdot 15$ & $\left.\begin{array}{r}78 \cdot 70 \\
116 \cdot 38 \\
115 \cdot 20 \\
136 \cdot 75 \\
110 \cdot 00\end{array}\right\}$ & 106.97 & $\left.\begin{array}{r}6 \cdot 70 \\
47 \cdot 13 \\
42 \cdot 20 \\
75 \cdot 25 \\
80 \cdot 00\end{array}\right\}$ & 39.03 \\
\hline 2 & $\begin{array}{l}1 \\
2 \\
3 \\
4 \\
5\end{array}$ & $\begin{array}{c}8 \\
10 \\
8(2) \\
6(4) \\
2(6)\end{array}$ & $\left.\begin{array}{r}91 \cdot 00 \\
105 \cdot 20 \\
80 \cdot 75 \\
76 \cdot 00 \\
76 \cdot 00\end{array}\right\}$ & 89.24 & $\left.\begin{array}{l}106 \cdot 25 \\
127 \cdot 40 \\
136 \cdot 87 \\
119 \cdot 83 \\
133 \cdot 00\end{array}\right\}$ & $123 \cdot 65$ & $\begin{array}{l}47 \cdot 25 \\
48 \cdot 30 \\
78 \cdot 37 \\
73 \cdot 00 \\
79 \cdot 00\end{array}$ & $61 \cdot 32$ \\
\hline 3 & $\begin{array}{l}1 \\
2 \\
3 \\
4 \\
5\end{array}$ & $\begin{array}{c}3(6) \\
10 \\
10 \\
7(2) \\
2(1)\end{array}$ & $\left.\begin{array}{r}157.00 \\
87.40 \\
135.90 \\
108 \cdot 29 \\
142 \cdot 50\end{array}\right\}$ & 117.09 & $\left.\begin{array}{r}86 \cdot 33 \\
109 \cdot 20 \\
107 \cdot 60 \\
127 \cdot 71 \\
110 \cdot 00\end{array}\right\}$ & 110.66 & $\left.\begin{array}{l}91 \cdot 67 \\
25 \cdot 20 \\
39 \cdot 90 \\
89 \cdot 14 \\
99 \cdot 50\end{array}\right\}$ & $54 \cdot 69$ \\
\hline 4 & $\begin{array}{l}1 \\
2 \\
3 \\
4 \\
5\end{array}$ & $\begin{array}{r}10 \\
10 \\
8 \\
9 \\
10\end{array}$ & $\left.\begin{array}{r}86 \cdot 90 \\
104 \cdot 00 \\
81 \cdot 13 \\
85 \cdot 44 \\
84 \cdot 20\end{array}\right\}$ & $>88 \cdot 70$ & $\left.\begin{array}{l}111 \cdot 60 \\
142 \cdot 40 \\
120 \cdot 45 \\
114 \cdot 11 \\
122 \cdot 40\end{array}\right\}$ & $122 \cdot 45$ & $\left.\begin{array}{l}17 \cdot 80 \\
34 \cdot 40 \\
21 \cdot 37 \\
16 \cdot 33 \\
17 \cdot 40\end{array}\right\}$ & $21 \cdot 57$ \\
\hline 5 & $\begin{array}{l}1 \\
2 \\
3 \\
4 \\
5\end{array}$ & $\begin{array}{l}10 \\
10 \\
10 \\
10 \\
10\end{array}$ & $\left.\begin{array}{l}68 \cdot 20 \\
61 \cdot 90 \\
75 \cdot 10 \\
68 \cdot 10 \\
70 \cdot 30\end{array}\right\}$ & $68 \cdot 76$ & $\left.\begin{array}{l}71 \cdot 50 \\
64 \cdot 80 \\
76 \cdot 30 \\
65 \cdot 00 \\
69 \cdot 00\end{array}\right\}$ & $69 \cdot 32$ & $\left.\begin{array}{l}7 \cdot 10 \\
7 \cdot 70 \\
8 \cdot 00 \\
7 \cdot 30 \\
7 \cdot 80\end{array}\right\}$ & 7.58 \\
\hline 6 & $\begin{array}{l}1 \\
2 \\
3 \\
4 \\
5\end{array}$ & $\begin{array}{r}10 \\
9 \\
8 \\
10 \\
10\end{array}$ & $\left.\begin{array}{l}48 \cdot 90 \\
55 \cdot 33 \\
57 \cdot 63 \\
52 \cdot 70 \\
46 \cdot 30\end{array}\right\}$ & $-51 \cdot 87$ & $\left.\begin{array}{l}79 \cdot 40 \\
83 \cdot 56 \\
78 \cdot 38 \\
73 \cdot 40 \\
68 \cdot 20\end{array}\right\}$ & $76 \cdot 36$ & $\left.\begin{array}{l}9 \cdot 20 \\
9 \cdot 56 \\
8 \cdot 00 \\
8 \cdot 90 \\
7 \cdot 20\end{array}\right\}$ & $8 \cdot 57$ \\
\hline
\end{tabular}

The non-flowering individuals are shown in brackets. 
The populations from railway tracks are also homogeneous with respect to height, although there are clearly marked differences between these populations in their mean flowering times (table 3). The populations from garden habitats, on the other hand, differ both in their mean height as well as in their mean flowering time.

TABLE 3

Analysis of variance on each habitat group individually

\begin{tabular}{|c|c|c|c|c|c|}
\hline \multicolumn{6}{|c|}{ Analysis of variance on each habitat group individually } \\
\hline Habitat & Item & d.f. & $\begin{array}{c}\text { M.S. } \\
\text { (Height) }\end{array}$ & $\begin{array}{c}\text { M.S. } \\
\text { (R. width) }\end{array}$ & $\begin{array}{c}\text { M.S. } \\
\text { (F. time) }\end{array}$ \\
\hline 1 & $\begin{array}{l}\text { Populations } \\
\text { Between families } \\
\text { Within families }\end{array}$ & $\begin{array}{r}3 \\
16 \\
127\end{array}$ & $\begin{array}{l}6308 \cdot 034 \\
3940 \cdot 841^{* *} \\
1389 \cdot 413\end{array}$ & $\begin{array}{l}2526.093 \\
1681 \cdot 747 * * * \\
402 \cdot 662\end{array}$ & $\begin{array}{c}12,585 \cdot 065^{*} \\
3,523.574 * * * \\
143.686\end{array}$ \\
\hline 2 & $\begin{array}{l}\text { Populations } \\
\text { Between families } \\
\text { Within families }\end{array}$ & $\begin{array}{r}1 \\
8 \\
87\end{array}$ & $\begin{array}{l}6909 \cdot 316^{* * * *} \\
210 \cdot 022 \\
115 \cdot 543\end{array}$ & $\begin{array}{l}1201 \cdot 300 \\
283 \cdot 879 * * * \\
60 \cdot 744\end{array}$ & $\begin{array}{l}23.960 * * * \\
5.081 \\
3.920\end{array}$ \\
\hline
\end{tabular}

Habitat 1: disused railway tracks.

Habitat 2: gardens.

The populations also differ in their total phenotypic variance, which, as is the case with their respective character means, tends to be related to differences between habitats (table 4). Thus, populations from garden habitats are clearly less variable than those from railway tracks. Also, the railway track populations, though homogeneous with respect to rosette

TABLE 4

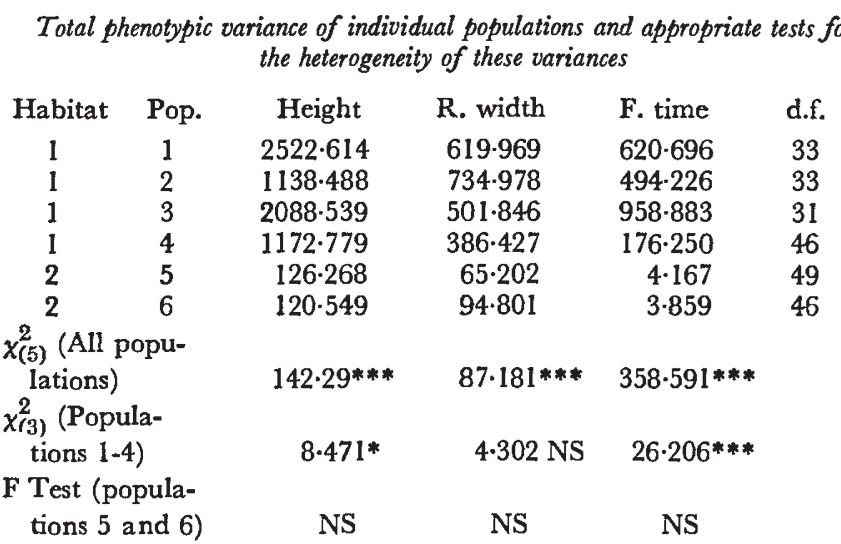

width, differ considerably in the amount of variation they contain for flowering time and height, although it is possible that the differences with respect to height are solely due to the large differences in the mean expression of the populations, i.e. it is a scaling effect.

\section{(ii) Variation within populations}

The populations differ not only in their character means, and the distribution of variation about these means, but also with respect to the distribution of variation within and between their families, i.e. the populations differ 
in their structure (table 5). Thus there are significant differences between families in populations 1 and 3 with respect to height, in populations 1,4 and 6 with respect to rosette width and in populations $1,2,3,4$ and 6 with respect to flowering time. It is therefore clear that there is genetic variation with respect to one or more characters in all populations with the exception of population 5.

For any particular character, the absence of genetic variation in a population suggests fixation of the genes controlling that character, assuming, of course, that the apparent absence of variability is not simply due to an accident of sampling. If the cause is fixation, then, on the one extreme, the genes controlling height at flowering appear to be fixed in all but two of the populations, whilst the genes controlling flowering time appear to have become fixed in population 5 only.

TABLE 5

Analyses of variance of individual populations

\begin{tabular}{|c|c|c|c|c|c|c|}
\hline Habitat & Pop. & Item & d.f. & $\begin{array}{c}\text { M.S. } \\
\text { (Height) }\end{array}$ & $\begin{array}{c}\text { M.S. } \\
\text { (R. Width) }\end{array}$ & $\begin{array}{c}\text { M.S. } \\
\text { (F. time) }\end{array}$ \\
\hline 1 & 1 & $\begin{array}{l}\text { Between families } \\
\text { Within families }\end{array}$ & $\begin{array}{r}4 \\
29\end{array}$ & $\begin{array}{l}9101 \cdot 679 * * \\
1615 \cdot 157\end{array}$ & $\begin{array}{l}3235 \cdot 661^{* * *} \\
259 \cdot 183\end{array}$ & $\begin{array}{l}4920 \cdot 412 * * * \\
27 \cdot 632\end{array}$ \\
\hline 1 & 2 & $\begin{array}{l}\text { Between families } \\
\text { Within families }\end{array}$ & $\begin{array}{r}4 \\
29\end{array}$ & $\begin{array}{l}1137 \cdot 754 \\
1138 \cdot 590\end{array}$ & $\begin{array}{r}1056 \cdot 164 \\
690 \cdot 676\end{array}$ & $\begin{array}{c}1771 \cdot 367 * * \\
318 \cdot 068\end{array}$ \\
\hline 1 & 3 & $\begin{array}{l}\text { Between families } \\
\text { Within families }\end{array}$ & $\begin{array}{r}4 \\
27\end{array}$ & $\begin{array}{l}4741 \cdot 372 * \\
1695 \cdot 270\end{array}$ & $\begin{array}{l}981 \cdot 781 \\
430 \cdot 744\end{array}$ & $\begin{array}{c}6850 \cdot 213^{* * *} \\
86.094\end{array}$ \\
\hline 1 & 4 & $\begin{array}{l}\text { Between families } \\
\text { Within families }\end{array}$ & $\begin{array}{r}4 \\
42\end{array}$ & $\begin{array}{r}783 \cdot 082 \\
1209 \cdot 943\end{array}$ & $\begin{array}{c}1453 \cdot 382 * * \\
284 \cdot 812\end{array}$ & $\begin{array}{l}552 \cdot 304 * * \\
140 \cdot 435\end{array}$ \\
\hline 2 & 5 & $\begin{array}{l}\text { Between families } \\
\text { Within families }\end{array}$ & $\begin{array}{r}4 \\
45\end{array}$ & $\begin{array}{l}225 \cdot 480 \\
117 \cdot 449\end{array}$ & $\begin{array}{l}231 \cdot 670 \\
504 \cdot 044\end{array}$ & $\begin{array}{l}1 \cdot 370 \\
4 \cdot 416\end{array}$ \\
\hline 2 & 6 & $\begin{array}{l}\text { Between families } \\
\text { Within families }\end{array}$ & $\begin{array}{r}4 \\
42\end{array}$ & $\begin{array}{l}194 \cdot 565 \\
113 \cdot 499\end{array}$ & $\begin{array}{c}336 \cdot 089 * * \\
71 \cdot 821\end{array}$ & $\begin{array}{l}8 \cdot 792 * \\
3 \cdot 389\end{array}$ \\
\hline
\end{tabular}

'These differences between populations emerge particularly clearly when the components of the mean squares of the items in table 5 are considered together with the proportion of the variation which falls to a comparison between families, i.e. the intra-class correlation coefficient, $t_{f}$ (table 6). For a given character there are clearly marked differences between populations in the proportion of the variation which falls to a comparison between families. For example, in the case of flowering time in populations 1 and 2, although the total variation displayed by these populations is similar, 97 and 41 per cent. of the variation respectively falls to a comparison between families. The difference between families is thus much greater in population 1 than 2 . Putting this another way, the absolute value of $\sigma_{w}^{2}$ in population 1 is much less than in population 2, which suggests that the individuals which comprise the families in these populations differ in their average heterozygosity. Similarly, the individuals comprising the families in population 4 appear to be more heterozygous than those in population 3. This may reflect a difference in the breeding system, the individuals in populations 1 and 3 being relatively more inbred than those in populations 2 and 4 . On this 
argument, however, a similar pattern should be found with respect to the other characters; with height, however, the reverse situation is found, for the absolute value of $\sigma_{w}^{2}$ in populations 1 and 3 is much greater than that in populations 2 and 4 . It seems likely, therefore, that some other factor is operating to produce these differences between populations. The distribution of variation in population 3 with respect to flowering time, for example, suggests that selection may be an important factor determining the differences in structure between these populations. In this population, the families fall into two distinct groups, an early-flowering group (families 2 and 3), and a late-flowering group to which the non-flowering individuals are confined (families 1, 4 and 5) (table 3; see also Jones, 1971 ; fig. 3). This strongly suggests that this population has a polymorphic structure of early-flowering individuals on the one hand and late-flowering individuals on the other.

\section{TABLE 6}

Components of variation and intraclass correlation coefficients

\begin{tabular}{|c|c|c|c|c|c|c|c|c|c|c|}
\hline \multirow[b]{2}{*}{ Habitat } & \multirow[b]{2}{*}{ Pop. } & \multicolumn{3}{|c|}{ Height } & \multicolumn{3}{|c|}{ Rosette width } & \multicolumn{3}{|c|}{ F. time } \\
\hline & & $\sigma_{w}^{2}$ & $\sigma_{b}^{2}$ & $t_{f}$ & $\sigma_{w}^{2}$ & $\sigma_{b}^{2}$ & $t_{f}$ & $\sigma_{v o}^{2}$ & $\sigma_{b}^{2}$ & $t_{f}$ \\
\hline 1 & 1 & $1615 \cdot 157$ & 116.761 & 6.8 & $259 \cdot 183$ & $464 \cdot 219$ & $64 \cdot 2$ & $27 \cdot 632$ & $763 \cdot 089$ & $96 \cdot 5$ \\
\hline 1 & 2 & 1138.590 & 0 & 0 & 873.420 & 0 & 0 & 318.068 & 222.577 & $41 \cdot 2$ \\
\hline 1 & 3 & $1695 \cdot 270$ & $511 \cdot 683$ & $23 \cdot 2$ & & 0 & 0 & 86.094 & $1136 \cdot 234$ & 93.0 \\
\hline 1 & 4 & 996.512 & 0 & 0 & $284 \cdot 812$ & 124.541 & $30 \cdot 4$ & $140 \cdot 304$ & $43 \cdot 895$ & $23 \cdot 8$ \\
\hline 2 & 5 & $171 \cdot 465$ & 0 & 0 & 367.857 & 0 & 0 & 2.893 & 0 & 0 \\
\hline 2 & 6 & 154.032 & 0 & 0 & 71.821 & $28 \cdot 165$ & $28 \cdot 2$ & $3 \cdot 389$ & 0.576 & 14.5 \\
\hline
\end{tabular}

$\sigma_{w}^{2}=$ within family variance.

$\sigma_{b}^{2}=$ between family variance.

$t_{f}=$ intraclass correlation coefficient (in percentages).

Where the between family mean square is not significant (table 5)

$\sigma_{b}^{2}$ has been taken to be zero.

In appropriate circumstances, and with the usual assumptions about the mode of inheritance, the intraclass correlation coefficient may be used to estimate the heritability of a character. Three pieces of information are required, however, before this can be attempted with the present data. Firstly, it is necessary to obtain an estimate of the frequency of outcrossing which occurs in natural populations of this species and, although investigations designed to provide such information are at present under way, no information is yet available on this point. Secondly, assuming that some outcrossing does occur in populations of the species, it is essential to know whether the paternal parentage is single or multiple, i.e. whether the members of a family are full or half sibs. Thirdly, the members of a sibship will appear to be more closely related than would otherwise be the case if maternal effects are of importance in the determination of the character in question. In view of the evidence from studies on inbred lines (Mackay, 1967; Westerman, 1971), it is likely that maternal effects are present in this material, although their effect relative to that of nuclear inheritance is not known. For these reasons, no attempt can be made to estimate heritabilities from the present data. 


\section{Discussion}

Studies on wild populations of plant and animal species have repeatedly shown the presence of considerable amounts of genetic variation with respect to a wide range of characters (e.g. Dobzhansky, 1951; Ford, 1964). The organisation of this variation can be considered at two levels, namely, that concerning differences between populations on the one hand, and within populations on the other. Differences observed between populations may of course be generally taken to reflect adaptation to diverse environmental conditions. Furthermore, if the populations come from distinct habitats, the distribution of variation can frequently be related to variation in some major environmental factor such as, for example, daylength (Cooper, 1950), or soil-nutrients (Snaydon, 1962a; Jain and Bradshaw, 1966).

In the present experiment also, the major difference between populations appears to be closely related to their origins. Populations 5 and 6 were found in garden habitats in which it is likely that they are subject to a special type of selection by gardening activities. Such conditions will favour these genotypes with a short vegetative phase of growth and those which therefore flower uniformly early. The low average rosette width and height of these populations may also represent the adaptational diversion of energy from vegetative to reproductive growth. In contrast, the populations from railway tracks are later flowering and are taller with larger rosettes. Similar differences have been reported in other species which are found in both weed and non-weed habitats. For example, the weed form of Eupalorium microstamon flowers earlier than the non-weed form of this species (Baker, 1965). Imam and Allard (1965) also found that the early flowering habit of some Californian Wild Oat populations is closely related to the practice of weed control.

Before turning to discuss the significance of differences observed between populations within habitats, and the differences in structure of individual populations, two points need to be raised concerning the validity of any further conclusions. Firstly, five plants only were sampled from each population and it is thus possible that the situation observed is due more to chance than to genuine differences between populations, or between families, as the case may be. Further evidence, however, some of which concerns the populations considered here and which will be presented in later papers in this series, leaves little doubt that much of the variation described here is in fact genuine.

The second point concerns the relationship between the performance of material in a laboratory environment and its natural habitat. The results from other experiments, to be presented in later papers, show that much of the variation observed in material from natural populations grown in the laboratory is unlikely to be expressed under natural conditions because most genotypes from British populations will respond and, indeed, some require, a period of low temperature before they will flower. On the other hand, although most of the genetic variation with respect to flowering time may thereby be concealed in a natural population, such variation must be of significance, albeit in the pleiotropic determination of other characters not measured here.

The variation observed between populations within habitats presumably reflects adaptation to local conditions. The garden populations come from 
distinct geographical areas, one from Birmingham and the other from near London. It is not surprising, therefore, to find differences between these populations both in their mean flowering time and height.

Although the populations from disused railway tracks were all obtained locally they clearly differ with respect to their mean flowering times. This may reflect either the independent evolution of individual populations or, alternatively, clinal variation. For, although each of the sampling sites is separated by a distance of up to 10 miles, it is possible that they form part of the same general population.

An interpretation of the variability found within these populations is less easy than that of differences between them. On a simple view it might be expected that within a population natural selection would act in such a manner that individuals with the fittest genotype supplant all others in the population, thereby resulting in genetic identity for all the members of that population. However, it is clear from the present results and the results of investigations concerning other species (e.g. Lawrence, 1965, 1969; Allard, Jain and Workman, 1968; Arthur, 1969; Hayward and Nsowah, 1969), that this rarely appears to be the case in natural populations. The wide range of variation in populations has been explained in several ways; for example, seasonal fluctuations in selection values (Allard and Workman, 1963) or adaptation to heterogeneous environments (Snaydon, 1962b).

Taking the present results at face value, it appears that the sites from which the material was sampled differ with respect to the number of niches in which the species can grow. For instance, the presence of much genetic variation in the garden population from Ruislip (population 6) suggests that this population is adapted to a more heterogeneous environment than the population from Cannon Hill (population 5). The wide range of variation observed in the populations from railway tracks appears to reflect adaptation to a highly heterogeneous environment. For example, the bimodal distribution of variation with respect to flowering time in the population from Luddington (Population 3) implies adaptation to at least two inches in the environment. In the remainder of these populations the distribution of variation is not so well defined and thus may well reflect adaptation to an even wider range of environmental conditions.

\section{SUMmary}

1. The distribution of variation with respect to three quantitative characters has been examined in six natural populations of Arabidopsis thaliana from two contrasting habitats.

2. The major difference between the populations is closely related to a difference between habitats. Thus, populations from garden habitats are less variable, flower earlier, have smaller rosettes and are shorter than populations from disused railway tracks.

3. With the exception of one of the garden populations, all populations show genetic variation with respect to one or more character. The proportion of the variation which falls to comparisons between families, however, varies considerably from one population to another, which suggests that the structure of populations of this species is capable of considerable modification by natural selection acting in a heterogeneous environment. 
4. The type of selection which has possibly brought about these differences both in the structure and mean expression of the populations is discussed.

Acknowledgments.- I am greatly indebted to Dr M. J. Lawrence for his advice and guidance, and to Professor J. L. Jinks for his helpful suggestions. The work was undertaken whilst in receipt of a Science Research Council Studentship.

\section{REFERENGES}

ALLARD, R. W., JAIN, S. K., AND WORKMAN, P. L. 1968. The genetics of inbreeding populations. Adv. in Genetics., 14, 55-131.

ALlard, R. W., AND WORKMAN, P. L. 1963. Population studies in predominantly selfpollinated species. IV. Seasonal fluctuations in estimated values of genetic parameters in Lima bean populations. Evolution, 17, 470-480.

ARTHUR, A. E. 1969. Variation in natural populations of Papaver dubium. Ph.D. thesis, Univ. of Birmingham.

BAKER, H. G. 1965. Characteristics and modes of origin of weeds. In The Genetics of Colonising Species, Ed. Baker, H. G., and Stebbins, G. L., pp. 147-172. Academic Press, New York and London.

COOPER, J. P. 1950. Daylength and head formation in the ryegrasses. F. Brit. Grassland Soc., $5,105-112$.

Dobzhansky, т. 1951. Genetics and the Origin of Species. Columbia University Press, New York.

FORD, E. B. 1964. Ecological Genetics. Methuen, London.

HAYWARD, M. D., AND NSOWAH, G. F. 1969. The genetic organisation of natural populations of Lolium perenne. VI. Variation within populations. Heredity, 24, 521-528.

IMAM, A. C., AND ALLARD, R. W. 1965. Population studies in predominantly self-pollinated species. IV. Genetic variability between and within natural populations of wild oats from differing habitats in California. Genetics, 51, 49-62.

JAIN, s. K., AND BRADSHAW, A. D. 1966. Evolutionary divergence among adjacent plant populations. I. The evidence and its theoretical analysis. Heredity, 21, 407-441.

JONES, M. E. 1971. The population genetics of Arabidopsis thaliana. I. The Breeding system. Heredity, 27, 39-50.

LAWRENCE, M. J. 1965. Variation in wild populations of Papazer dubium. I. Variation within populations; Diallel crosses. Heredity, 20, 183-204.

LAWRENCE, M. J. 1969. Variation in wild populations of Papaver dubium. II. Variation between populations. Heredity, 24, 337-345.

MACKAY, G. R. 1967. Test crossing in lines of Arabidopsis thaliana. M.Sc. thesis, Univ. of Birmingham.

SNAYDON, R. w. 1962a. The growth and competitive ability of contrasting natural populations of Trifolum repens on calcareous and acid soils. F. Ecol., 50, 439-447.

SNAYDON, R. w. 1962b. Micro-distribution of Trifolum repens and its relation to soil factors. 7. Ecol., 50, 133-143.

WESTERMAN, JANE M. 1971. Genotype-environment interaction and developmental regulation in Arabidopsis thaliana. II. Inbred Lines; analysis. Heredity, 26, 93-106. 